\section{- pensamento filosófico como uma rede virtual: afualizações em tempos de redes comunicacionais}

Francisco E. Menezes Martins

Dr. Ciências Comunicação - Univ. Complutense de Madrid

Prof. do Programa de Pós-grad. da FAMECOS/PUCRS
A COMUNICAÇ̃̃o, NA BUSCA de referências sobre os reflexos de sua prática, deve aproximar-se da filosofia para colher em pleno tempo das redes ${ }^{1}$ uma rede de pensamento dispersa pelo tempo, mas que forma o virtual da filosofia, a instância da conservação e da potência de ser atualizada como perspectiva teórica e como orientação em pesquisas nesta área.

Criando uma imagem, pode-se ver o rio de Heráclito, o fluxo do devir. Em uma margem, a comunicação em redes digitais, a cultura pós-moderna, a vertigem evo-lucionista da relação com a técnica, a globalização e as injustiças sociais da chamada sociedade de consumo ou da informação. Do outro lado do rio, a filosofia, com suas escolas, sistemas e doutrinas: um permanente estado de debate virtual das questões do ser, do homem e do mundo.

É, portanto, objetivo deste texto propor a "construção" de pontes entre a comunicação e a filosofia, sendo considerados o pensamento de autores como Nietzsche, Heidegger, Deleuze, Vattimo e Baudrillard. Ressalto que o trabalho aqui apresentado possui um "tom" ensaístico e forma um conjunto de primeiras impressões, cujo resultado é parcial, colhidas em uma pesquisa que se destina a delinear um mapa conceptual do pensamento filosófico apreendido em uma rede de autores para contribuir com as análises contemporâneas da comunicação.

Assim como o tempo que separa, passa e conserva o virtual, as percepções se multi- 
plicam na mesma medida de sua capacidade de serem formações individuais dotadas de uma lógica própria de sentido. A história do homem seria a história do tempo de seus horizontes cuja ampliação em dobras remete à história da filosofia virtual, ${ }^{2}$ expressão utilizada por Deleuze, indicando que o atual soluciona as problemáticas do virtual numa rede infinita que aproxima os tempos conservados virtualmente.

Considerando o atual como uma partícula que se desprende do virtual, o presente como uma atualização do tempo virtual, entende-se que a cada época, dependendo da intensidade de tais relações, pode-se vislumbrar o grau de liberdade de pensamento e expressão para contemplar, refletir e comunicar o virtual. A riqueza do mundo está no plano de imanência, no fluxo heraclitano dotado do trágico eterno retorno captado por Nietzsche.

Tentar atualizar o mundo, hoje em dia, é tarefa da mídia já que paralelo ao aumento de informações (virtual) há o aumento das mediações e soluções em rede. Isto não significa que o virtual da técnica, o ciberespaço, venha sendo atualizado, mas que ele é fonte de simulacros. Ontolo-gicamente, o virtual comporta, segundo Deleuze, vários planos e para cada qual existe um ser, um Uno-Todo, que não é divisível mas é multiplo, que é totalidade enquanto âmbito do plano, mas não significa nada para outro plano. A figura montada é a da teia de aranha. Deleuze tece sua teia na qual somos apanhados pela ação genea-logista deste pensador. Remete ao inícios dos tempos, busca na fonte primeira, no imanar do devir, no plano de imanência, a essência do homem enquanto fluxo, finitu-de, retorno e fé no devir.

A era dos simulacros, desde o ponto de vista de Baudrillard, apresenta as marcas do que desapareceu. O objeto é irônico e o sujeito, sua vítima fatal. Da pretensão de poder sobre o objeto, ele perdeu a vontade de poder como sujeito que afirma. Nesta perspectiva, o virtual informático seria um imenso congelador que conserva o que nele foi guardado.

Observa-se que sua característica lúdica e onírica revela o grau de saberes em circulação. O devir software da técnica dissolve-se e confunde-se com o devir do mundo.

"Parece, en efecto, que si la ilusión del mundo se ha perdido, la ironía, por su parte ha pasado a las cosas. Parece que la técnica ha cargado com toda la ilusión que nos ha hecho perder, y que la contrapartida de la pérdida de la ilusión es la aparición de uma ironía objetiva de este mundo. La ironía como forma universal de la desilusión pero tambiém del estratagema por lo qual el mundo se oculta de la ilusión radical de la técnica, y el secreto(el de la continuación de la nada) detrás de la banalidad universal de la información." ${ }^{3}$

Martin Heidegger apresenta a metafí-sica da decadência à fase final com o advento da técnica. Baudrillard interpreta a idéia e propõe o caso de um crime perfeito. Seguindo o nihilismo, o sociólogo francês pensa que:

"Contrariamente al discurso de lo real, que apuesta que hay algo más que la nada, y se pretende basado en la garantía de un mundo objetivo y descifrable, el pensamiento radical, por su parte, apuesta en favor de la ilusión del mundo. Se pretende ilu-sión devolviendo la no-veracidad de los hechos, la no significación del mundo, formulando la hipótesis o-puesta de que no hay nada en lugar de algo, y persiguiendo esta nada que corre bajo la aparente continuidad del sentido." ${ }^{4}$

Busca-se em Nietzsche a ruptura ontológica a golpes de martelo para situar em sua genealogia a cena histórica platônica da divisão do mundo das "aparências" do mundo "verdadeiro". Considero, apesar da dissimulação da intensidade das influências 
nietzcheanas, que o próprio Baudril-lard fez cortina de fumaça durante uma conversa em Porto Alegre, em outubro de 1997, em que ele atualizou a perspectiva proposta por Nietzsche em $\mathrm{O}$ crepúsculo dos ídolos, exposta em quatro teses que aqui transcrevo integralmente, para ser fiel ao golpe pretendido pelo autor:

"Primera tesis: Las razones por las que se ha considerado que 'este' mundo es aparente constituyen más bien el fundamento de su realidad; cualquier outra forma de realidad resulta indemonstrable.

Segunda tesis: Las características que son atribuídas al 'verdadero ser' de las cosas son precisamente los rasgos distintivos del no ser, de la nada; 'el mundo verdadero' ha sido concebido a base de contradecir el mundo real. Ese presunto 'mundo verdadero' es en realidad un mundo aparente por no ser más que una ilusión de óptica moral.

Tercera tesis: No tiene sentido inventar fábulas respecto a 'outro' mundo distinto a éste siempre y cuando no estemos movidos por un instintivo a calumniar, a empequeñecer, a recelar de la vida. En este caso nos vengamos de la vida imaginando com la fantasía 'outra' vida distinta y 'mejor que 'esta'. Cuarta tesis: Dividir el mundo en 'verdadero' y 'aparente', ya sea al modo de Kant (el último término, un cristianismo perverso), no es más que índice de vida descendente. El hecho de que el artista valore más la apa-riencia que la realidad no representa una objeción a esta tesis, habida cuenta de que en este caso 'la apa-riencia' equivale aquí también a la realidad, sólo que seleccionada, refor-zada, corregida. El artista trágico no es un pesimista; afirma todo lo problemático y terrible; es dionisíaco." ${ }^{5}$

A noção de atribuir ao mundo um sig- nificado e uma finalidade são metas históricas das religiões e da filosofia. Uma vez que o mundo não responde aos interesses do sujeito é impreterível à vontade de verdade que seja construído um mundo manipulável e submetido à mesquinharia dos que se proclamam arautos da moral e da verdade e contra a imprecisão da sensibilidade e dos sentidos.

Se "o ser não é" significa que ele nunca foi e ao nunca ter sido desmente o que lhe atribuíram. Leva-se em conta que o ser é o desaparecimento, que o que sempre foi afirmado na verdade é uma negação e o que sempre foi negado é a maior afirmação. Como pondera o pensamento nietzs-cheano com o qual aqui me somo, a maior condição da vontade de poder (potência) é atribuir ao tempo a condição de afirmar o ser em seu eterno retornar. Isto significa também que a relação atual/virtual contempla o ser/tempo como sendo o plano de imanência.

"Em todos os casos, a distinção entre o virtual e o atual corresponde à cisão mais fundamental do tempo, quando ele avança diferenciando-se segundo duas grandes vias: fazer passar o presente e conservar o passado. $\mathrm{O}$ presente é um dado variável medido por um tempo contínuo, isto é, por um suposto movimento numa única direção: o presente passa à medida que esse tempo se esgota. É o presente que passa que define o atual (...) A relação do atual com o virtual constitui sempre um circuito, mas de duas maneiras: ora o atual remete a virtuais como a outras coisas em vastos circuitos, onde o virtual se atualiza, ora o atual remete ao virtual como o seu próprio virtual, nos menores circuitos onde o virtual cristaliza com o atual. O plano de imanência contém a um só tempo a atualização como relação do virtual com outros termos, e mesmo o atual com o qual o virtual se inter-cambia." 6

Sendo esta relação algo incessante, 
contínuo e imanente, vem à tona com a intenção de somar-se à denúncia filosófica e ontológica da fábula na qual o mundo se converteu. Esta corrente de pensamento repele a supremacia do "verdadeiro" sobre o "aparente" e levanta o problema de que verdade e sensibilidade não se separam em mundos distintos, mas que se alternam na imanência que as faz fluir.

Colocando Nietzsche, Baudrillard e Deleuze na mesma teia pode-se obter conceitos como o de que o "mundo verdadeiro" contemporâneo é o "mundo do simulacro" e que o "mundo das aparências" é o "mundo do real" agonizante pela sua elevação à potência da hiper-realidade: um real acrescido de suas imagens, que ao invés de aumentálo, acaba por faze-lo desaparecer. E é exatamente o desaparecimento do real como "mundo das aparências" que faz do simulacro a imagem do "mundo verdadeiro".

$\mathrm{Na}$ impossibilidade de se atualizar um virtual cada vez mais rizomático, numa era de crescente mundialização quando a técnica, as imagens de síntese e a mídia inauguram novos limites e novas perspectivas, as pessoas se valem da credibilidade moral dos sábios de hoje: os comunicadores, jornalistas, publicitários e marketeiros. Ao contrário de outras épocas quando a sabedoria recaía sobre os filósofos, os religiosos ou os políticos. A voz mais alta é a da mídia. A luz mais brilhante é a da mídia. A mídia é coração e cérebro da cultura pósmoderna.

A mesma vontade de dominar a verdade do mundo através de suas representações encontra-se no platonismo contemporâneo: a mídia, que estabelece e julga os valores que ela mesma estabeleceu. É também uma prótese retórica para fazer circular a política. Tire-se sua máscara de legitimadora da ordem e da finalidade do mundo e sobrará a mesma vontade de objetividade, que em última análise é uma egoísta e negativa manifestação da vontade de verdade, da vontade de lucrar vendendo a fábula, a cada dia que passa, com recursos mais sofisticados e refinados, do simulacro do real à realidade do virtual.

A mídia atualiza a questão ontológica de que o nada como continuação é o pior inimigo do algo. Desde uma perspectiva comparativa, nota-se que Nietzsche falava na chegada em retorno do nihilismo, enquanto Baudrillard se debruça sobre a questão da continuação do nada como fluir. Ambos se complementam no devir do nihilismo: fluxo e retorno. Ao estabelecer o mundo como construção técnico-retórica, o discurso midiático é idealista e remete a uma fantasmagórica dimensão de espectros simbólicos. Desta forma, "o nada combatido em nome de um algo transmitido", torna-se um slogan da cultura midiá-tica pós-moderna. Ao ser invertido passa a ser uma causa de batalha da desmas-caradora filosofia contemporânea apoiada em Nietzsche e Heidegger: " $\mathrm{O}$ algo combatido em nome de um nada transmitido".

Os ídolos da pós-modernidade são a virulência de signos apontada por Baudrillard, os quais, neste estado viral, não sucumbem a uma filosofia a golpes de martelo. Haja martelo para tantos ídolos. Talvez uma vacina letal na moral do rebanho, segundo a ótica nietzscheana, com alta dose de afirmação da vontade de potência ajudasse, mas a reprodução em rede das viroses banais desafiam esta vacina nihilis-ta.

Os pensadores contemporâneos possuem o século $X X$ como laboratório e da relação entre a história e a filosofia que imortaliza a existência de seus autores fazem suas análises levando em conta o ponto onde determinado filósofo abandonou a continuidade de seu trabalho. O pensamento segue a tendência de ser apenas uma volta a mais numa corrida que jamais terá linha de chegada. É como se o tempo em devir fosse uma pista olímpica onde cada filósofo corresse uma volta e entregasse o bastão (seu legado, sua obra) àquele pesquisador que desejasse correr em sua raia, 
já que na mesma pista podem correr muitos e nesta pista virtual podem pensar muitos, ao mesmo tempo e em eterno revezamento. Assim, a vantagem do tempo é de quem vive depois, mas talvez lhe falte o presente que passou, restando-lhe o passado que se conservou.

No crepúsculo deste século proclama-se o fim das utopias. Primeiro, Lyotard enterrou as metanarrativas que incluiam as grandes utopias, mas a pós-modernidade, em seu auto-discurso em nome da autoregulação, em todos os âmbitos da vida, parece não suportar nem sequer a nostalgia, já que a nostalgia que se nota é a nostalgia pela falta de nostalgia. O que era um discurso, o pós-moderno, contra um discurso maior, mas enfraquecido, o moderno, tornou-se o único discurso. Tornou-se também "mundo verdadeiro" ao afastar-se do que anunciava e aproximar-se do que combatia: a supremacia de um discurso. O grande discurso de hoje é o da mídia, mas ela já não tem centro é uma rede.

Da mesma forma, a globalização faz os países estarem ligados em rede. Rede de fluxos financeiros e culturais. Seria demasiado simplificador acreditar que pela ausência de um epicentro racional e moral, os efeitos metafísicos da modernidade cessariam. Heidegger pondera que a metafísica culmina com o fim da modernidade, mas que necessitaria ser superada como alguém que se recupera de uma doença mas que ainda ainda está convalescente. Em outras palavras, cada vez que um "mundo verdadeiro" chega às ruínas o homem da vontade de verdade levanta outro, aparentemente sensível ao mundo, mas que aos poucos busca legitimar-se como "verdadeiro".

Os conceitos como, por exemplo, pósmodernidade e globalização vem se aproximando das vias de dogmatização. Em ambos se inserem cada vez mais pesquisas acadêmicas. Tais estudos, quando apontam para o deslumbramento técnico-otimista, acabam por contribuir não com o projeto nihilista de desmascarar o algo para ver a continuidade do nada e nem com as atua- lizações do pensamento marxista, mas sim no fortalecimento do discurso da verdade do "mundo verdadeiro" do momento: economia globalizada, nações em crise de identidade, concentração do capital na mesma medida da expansão dos mercados, tecnologia democratizada pela ideologia neo-liberal da evolução do consumo como religião do "way of life" e do "comfort".

Observo, portanto, que para tentar responder à pergunta de qual seria a pesquisa em comunicação que pudesse abranger as circunstâncias contemporâneas, proponho a "construção" de pontes da margem da comunicação para a margem da filosofia e sobre a qual possam atravessar os fluxos de conhecimento, como uma necessária cristalização para possibilitar a reflexão e a crítica da comunicação desde perspectivas filosóficas distintas.

É necessário atualizar a filosofia e traze-la para perto da vida. O mundo superconectado pelas utopias futuristas e otimistas, como as filosofias neo-liberais e tecnorosas de Lévy e Negroponte, por exemplo, e pela circulação especulativa de quase tudo que possa ser formatado para a circulação midiática, requer sensibilidade humana, intenções honestas, consciência histórica e vivência filosófica.

"Quando o conhecimento é transformado em assunto de programas do tipo talk-shows ou documentários, como supunha Lyotard, e o conhecimento não traduzido às linguagens da mídia parece estar em excesso, não seria o momento de revisar nossos conceitos de informação e de saber?

Quando alguns jornalistas se limitam a "abrir aspas" e repetir o discurso das fontes para parecerem objetivos e intérpretes do " mundo verdadeiro", e quando alguns diretores de redação acreditam que a verdade é a média aritmética das capas dos principais jornais e, por isso, exaltam felicidade quando seu jornal é igual aos demais, igualmente "verdadeiro", não seria o 
momento de revisar nossos conceitos de jornalista e de jornalismo?"7

Hoje, a criatividade passa a ser privilégio de alguns publicitários e marketeiros e seus conceitos orientam as pessoas no consumo como religião do modo de vida, desde a escolha política até a marca de qualquer produto, para dissimular que na falta de opções de afirmar a vida, pelo menos resta a interatividade como estágio último da substituição da liberdade de se colocar diante das incertezas do devir, pela lógica da programação na qual as opções já foram pré-estabelecidas. O mundo "verdadeiro" das redes comunicacionais é o algo que mascara a existência do nada como o único algo, o ser •

\section{Notas}

1 Expressão utilizada no texto escrito por MENEZES MARTINS, F. E. "Informação e cultura no tempo das redes", in Tendências na Comunicação, Porto Alegre, L\&PM, 1998, que supõe a característica maior da era contemporânea, as profundas alterações nas percepções do tempo e do espaço com 0 advento das redes comunicacionais. Tal conceito abriga a noção de um tempo virtual e mediático, um tempo técnico, o próprio tempo das redes.

2 Título de um texto que dá nome ao livro escrito por ALLIEZ, E., Deleuze filsofia virtual, Rio de Janeiro, Editora $34,1996$.

3 BAUDRILLARD, J., El crimen perfecto, Barcelona, Anagrama, 1996, p. 102

4 BAUDRILLARD, J., El crimen perfecto, Barcelona, Anagrama, 1996, p. 135.

5 NIETZSCHE, F. W., El ocaso de los ídolos, Madrid, A-L Mateos, 1993, p. 60.

6 DELEUZE, G. in ALLIEZ, E. Deleuze filosofia virtual, Rio de Janeiro, Editora 34, 1996, pp. 55-56.

7 MENEZES MARTINS, F.E.," Assim teria falado Zara-tustra" in Revista FAMECOS: mídia, cultura e tecnologia, no. 7, 